\title{
Biochemical composition and condition in anchovy larvae Engraulis encrasicolus during growth
}

\author{
E. Díaz ${ }^{1, *}$, J. M. Txurruka ${ }^{2}$, F. Villate ${ }^{3}$ \\ ${ }^{1}$ AZTI, Arrantza Baliabideen Saila, Txatxarramendi ugartea, z/g. 48395 Sukarrieta, Bizkaia, Spain \\ ${ }^{2}$ Department of Genetics, Physical Anthropology and Animal Physiology, and \\ ${ }^{3}$ Department of Plant Biology and Ecology, University of the Basque Country, 48080 Bilbao, Spain
}

\begin{abstract}
Growth and condition of larval Engraulis encrasicolus larvae in the Bay of Biscay were analysed relative to their biochemical composition. Protein, carbohydrate, lipid, DNA and RNA contents of larvae were quantified during larval ontogeny to analyse changes associated with growth. Proteins were the main organic component of $E$. encrasicolus at every larval stage, followed by lipids and carbohydrates. The increase in relative protein content in terms of protein percentage $(\mathrm{P} \%)$ and the decrease in lipid relative content $(\mathrm{L} \%)$ of the total organic matter $(\mathrm{OM})$ with size observed are consistent with the definition of Type 1 larvae. Protein relative content increased until the $\mathrm{P} \%$ in larvae reached $\sim 71 \%$, whereas $\mathrm{L} \%$ and carbohydrate relative content $(\mathrm{CH} \%)$ declined, exhibiting minimum values of $\sim 20$, and $\sim 6 \%$, respectively. In general terms, the feeding condition of larvae, as defined by their RNA/DNA ratio, was good. Food did not seem to be a major factor limiting larval growth in the study area throughout late spring and early summer. The RNA/DNA ratio was size-related and increased during larval growth up to an asymptotic optimal value of $~ 3.6$ in postflexion larvae in relative protein content, in terms of protein percentage (P\%). The 'actual' RNA/DNA ratios found in a given larval population when compared with the 'starving' RNA/DNA ratio, and using an 'absolutely optimal' value as complementary information, could be used to determine the overall status of the population. Parental effect of low egg quality is a possible explanation of delayed ontogenetical development of larvae from July 2000.
\end{abstract}

KEY WORDS: Engraulis encrasicolus $\cdot$ Larvae $\cdot$ Condition $\cdot$ Biochemical composition · RNA/DNA · Protein/DNA · Growth · Ontogeny

\section{INTRODUCTION}

European anchovy Engraulis encrasicolus is one of the most abundant clupeoids of the Bay of Biscay and constitutes an important fishery resource in the Northeast Atlantic. Current anchovy stocks are very low. Recruitment has been low since 2002, with rates in 2006 and 2007 being the lowest since the beginning of monitoring in 1987 (ICES 2007). Population biomass of anchovy depends largely on recruitment, due to a high mortality rate, early reproduction and short life span (Motos et al. 1996). Thus, to understand the population dynamics, it is necessary to determine the factors affecting recruitment.
Starvation and predation are thought to be the 2 main agents of mortality in fish larvae (Bailey \& Houde 1989). Larger larvae show a higher capacity to avoid predation, obtain food, and resist starvation (Bailey \& Houde 1989), and therefore high growth rates are crucial to larval survival. These general ideas hold true for larval Engraulis encrasicolus: mortality declines with age, survival is growth rate-dependent (Rilling \& Houde 1999), and recruitment is related to larval growth (García et al. 2003). Consequently, E. encrasicolus should exhibit a metabolic strategy that favours optimal growth rates. Muscle is a key tissue for larval growth and is directly linked to locomotory ability and floatability. Since proteins are the main 
constituents of muscles, protein synthesis and accumulation must be one of the major priorities in the growth of E. encrasicolus larvae. However, fast-growing larvae devoting all available energy to growth might have a lower likelihood of surviving periods of intense resource scarcity (Post \& Parkinson 2001), or of outlasting critical, energy-demanding periods such as metamorphosis (Nursall 1989). For that reason there are trade-offs between the allocation of energy to growth and to storage products in organisms living in seasonal environments.

Quantitative analysis of the rate of deposition of different biochemical components during ontogeny should provide fundamental information about growth strategies in a biochemical context. In this context, RNA/DNA ratios can be used as an indicator of the protein synthesis capability of the cell and has proved to be a useful marker of nutritional condition and growth rate in fish larvae of different species (Buckley 1984, Clemmesen 1994). Use of the RNA/DNA ratio is based on the idea that the amount of DNA per cell is constant in somatic tissues of a given species, while the amount of RNA per cell is closely related to its protein synthesis capability. Additionally, the protein/DNA ratio is used to estimate cell size and, in muscle, it reflects the ratio of sarcoplasmic to nucleic volume (Rosa \& Nunes 2003).

The aims of this study were: (1) to document the biochemical composition and condition of Engraulis encrasicolus larvae during ontogeny; (2) to analyze the temporal variability in those patterns that could contribute to the recruitment variability; and (3) to determine the incidence of starvation among $E$. encrasicolus larvae in the Cantabrian Sea (Bay of Biscay).

\section{MATERIALS AND METHODS}

Study area. The study was carried out in the inner Bay of Biscay, on the Basque continental shelf area off San Sebastian, at $1^{\circ} 55^{\prime} \mathrm{W}$ and $43^{\circ} 20^{\prime}$ to $34^{\prime} \mathrm{N}$ (Fig. 1). The climate is temperate, oceanic, with moderate winters and warm summers. Since the shelf is very narrow hydrological conditions are highly variable, resulting from the mixing of coastal, shelf edge, and open ocean waters.

Sampling. Six surveys were undertaken during the spring to early summer period of 2 consecutive years: 3 in 2000 (6 May, 13 June and 5 July) and 3 in 2001 (10 April, 9 May and 14 June). Sampling was carried out at 3 stations (D1, D2 and D3) on a cross-shelf transect (Fig. 1). Larvae were captured by oblique tows using a $40 \mathrm{~cm}$ diameter bongo net with $335 \mu \mathrm{m}$ mesh size. Tows were conducted at a speed of 2 knots and completed in no more than $5 \mathrm{~min}$ per tow. All tows were performed during daytime and above the thermocline, to maximize the number of anchovy larvae collected (Palomera 1991). The depth of the thermocline was determined from CTD profiles and was found at $\sim 25 \mathrm{~m}$ in June 2000, 36 m in July 2000 and $\sim 30 \mathrm{~m}$ in June 2001. To describe and compare environmental conditions, temperature and salinity were measured at 4 equally distributed depths, from the surface to the depth of the thermocline.

Larvae were immediately removed from plankton samples using pipettes and transferred to cryovials filled with filtered seawater, frozen in liquid nitrogen and stored at $-80^{\circ} \mathrm{C}$ in the laboratory.

Laboratory analyses were restricted to larvae captured during June and July 2000 and June 2001, because sampling during these months yielded enough larvae for statistical analysis. Since the number of larvae from each individual sampling station was insufficient to allow statistical comparisons between stations, larvae from the 3 stations (D1, D2 and D3) were grouped for each month. To match the larval analyses, only between-month differences in temperature, salinity, and density were examined.

Laboratory analyses. Standard lengths (SL) of thawed anchovy larvae were measured using a binocular microscope fitted with an ocular micrometer. We used the medium SL of notochord flexion $(9.5 \mathrm{~mm}$, Ré 1996) to define size stages. Notochord flexion appears as a critical factor in the growth process, involving rapid development of specific morphological characteristics and changes in body shape (Blaxter 1988). In the case of Engraulis encrasicolus, larvae are more robust beyond notochord flexion (Bergeron 2000). We modelled 4 different stages: 2 before flexion $(5.5<\mathrm{SL}<7.5 \mathrm{~mm}$ and $7.5 \leq \mathrm{SL}<9.5 \mathrm{~mm})$ and 2 after flexion $(9.5 \leq \mathrm{SL}<11.5 \mathrm{~mm}$ and $\mathrm{SL} \geq 11.5 \mathrm{~mm})$. Larvae used in this study ranged from 5.3 to $14.8 \mathrm{~mm}$ SL.

Three subsamples of larvae were taken from each month and processed to estimate (1) organic matter (OM) content; (2) proteins, carbohydrates, and lipids; and (3) RNA and DNA. The numbers of larvae in each sub-sample by month and stage are provided in Table 1. All larvae were first rinsed with distilled water (to eliminate salt) and freeze-dried, followed by the determination of their dry weight using a Sartorius M3P microbalance. The first set of sub-samples was ashed at $450^{\circ} \mathrm{C}$ for $4 \mathrm{~h}$ and $\mathrm{OM}$ was calculated as the difference between dry weight and ash weight. The second set of sub-samples was used for the colorimetric quantification of proteins, carbohydrates and lipids. Larvae were initially homogenized in $900 \mu \mathrm{l}$ of water with a Branson Sonifier (mod B-12), and aliquots of $200 \mu \mathrm{l}$ (for proteins and lipids) and $400 \mu \mathrm{l}$ (for carbohydrates) were removed. Proteins were measured according to the Lowry et al. (1951) method, modified 


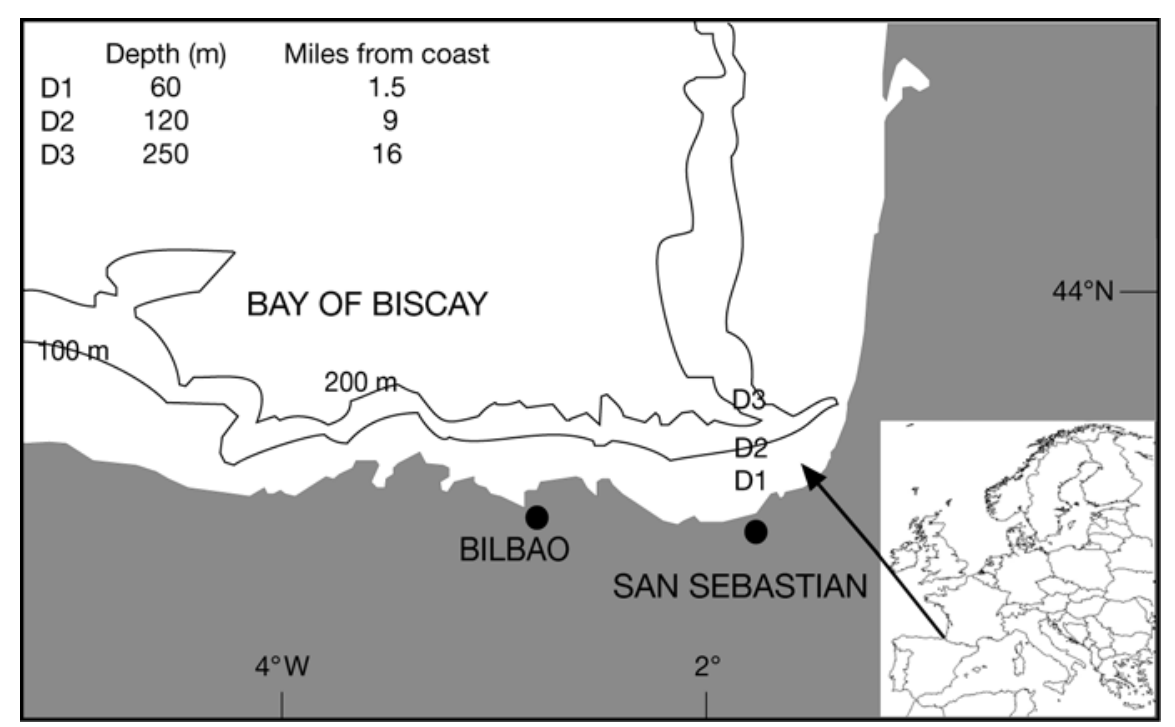

Fig. 1. Location of the sampling sites in the Bay of Biscay

by Markwell et al. (1978), using bovine serum albumin as the standard. Lipids were extracted following the method of Bligh \& Dyer (1959) and quantified with the sulfophosphovanillin method of Zöllner \& Kirsch (1962), with cholesterol as the standard. Carbohydrates were quantified following the procedure of Dubois et al. (1956), using glucose as the standard. The third set of sub-samples was used to determine nucleic acid content, which was quantified following the protocol proposed by the Precision and Accuracy of Tools in Recruitment Studies (PARS) project after several intercalibration trials (Belchier et al. 2004). Nucleic acids were extracted from the entire animal by homogenizing the larvae in Tris- $\mathrm{HCl}$ buffer $(0.05 \mathrm{M}$ Tris, $0.1 \mathrm{M} \mathrm{NaCl}, 0.01 \mathrm{M}$ EDTA, SDS $0.01 \%$, pH 8.0), using a Branson Sonifier. The homogenate was centrifuged and 2 aliquots were extracted from the supernatant. One was treated with RNAse to determine DNA content and the other was left without enzymatic treatment to determine the combined DNA+RNA content. The fluorescent dye ethidium bromide was used to quantify nucleic acids, and RNA fluorescence was obtained by subtracting the DNA fluorescence from the combined DNA+RNA fluorescence. Calibration curves were made with DNA Type I from calf thymus and RNA Type II from baker's yeast (both from SigmaAldrich). The mean standard curve slope ratio of DNA/RNA was $2.65 \pm 0.025$.

Data treatment. The ontogeny of the biochemical composition and condition of Engraulis encrasicolus larvae was examined using the following approaches: (1) analysis of the composition of preflexion and postflexion larvae was conducted with multivariate analysis of variance (MANOVA) statistical tests; (2) analysis of the isometric or allometric increase in each biomolecule with regard to OM increase was conducted using a log-log regression; (3) the relative importance of each biomolecule and changes in the RNA/DNA ratio in relation to OM during growth were evaluated by means of a hyperbolic function; and (4) the incidence of starvation among larvae was determined as proposed by Chícharo (1997) and Clemmesen (1994). All the statistical analyses were performed using Statgraphics Plus 5.0.

Prior to statistical analyses, the relationships between dry weight (DW) and SL, and that between $\mathrm{OM}$ and SL, were determined for each month using an exponential model: $\mathrm{DW}=a \cdot \exp (b \cdot \mathrm{SL})$. An analysis of covariance (ANCOVA) was used to test for significant differences among months. These equations were then used to estimate OM for larvae from the other 2 subsamples. Subsequently, the protein, carbohydrate, lipid, RNA, and DNA content of each larva was

Table 1. Engraulis encrasicolus. Number of larvae used for each quantification per month and stage-class. SL: standard length; OM: organic matter; PCL: proteins + carbohydrates + lipids; NA: RNA + DNA

\begin{tabular}{|lcccc|}
\hline Stage-class & Month & OM & PCL & NA \\
\hline SL $<7.5$ & June 2000 & 7 & 7 & 8 \\
(preflexion) & July 2000 & 12 & 18 & 7 \\
& June 2001 & 12 & 8 & 11 \\
$7.5 \leq \mathrm{SL}<9.5$ & June 2000 & 11 & 14 & 13 \\
(preflexion) & July 2000 & 16 & 27 & 11 \\
& June 2001 & 8 & 7 & 7 \\
$9.5 \leq \mathrm{SL}<11.5$ & June 2000 & 7 & 15 & 7 \\
(postflexion) & July 2000 & 3 & 2 & 2 \\
& June 2001 & 5 & 2 & 4 \\
SL $\geq 11.5$ & June 2000 & 2 & 3 & 2 \\
(postflexion) & July 2000 & 3 & 2 & 2 \\
& June 2001 & 6 & 7 & 5 \\
\hline
\end{tabular}


standardized by dividing by OM content and multiplying by 100 , resulting in percent protein $(\mathrm{P} \%)$, percent carbohydrate $(\mathrm{CH} \%)$, percent lipid (L\%), percent DNA (DNA\%) and percent RNA (RNA\%).

A MANOVA was used to determine whether there were differences among stages and months in the biochemical composition of the larvae. Stage, month and the interaction of stage and month were included in the MANOVA model as the independent (categorical) variables. Standardized values of $\mathrm{P} \%, \mathrm{CH} \%$ and $\mathrm{L} \%$ were the dependent variables in one MANOVA and standardized values of DNA\% and RNA\% were the dependent variables in another MANOVA. The interaction between stage and month was not significant in either MANOVA, so pair-wise comparisons between months and stages were performed using the Tukey post hoc test. When no significant differences were found between stages or between months, the average standardized value for the biochemical component and the total biomolecule content corresponding to that value were calculated for the specific stages or months. Finally, using the modeled values, the following parameters were calculated: (1) the amount of change in a given biochemical component between ontogenetic stages as the difference of the modeled content between subsequent stages; (2) the contribution of each component, in terms of percentage, to the total increase in larval OM content during growth; and (3) the RNA/DNA and protein/DNA ratios.

A log-log linear regression was used to determine whether the change in a given biochemical component was isometric or allometric with regard to OM increase. ANCOVA, with larval OM as a covariate, was used to compare the log-log regression models. When no significant differences were found between months, a common equation was calculated. Slope values close to 1 indicate an isometric growth pattern while slope values $<1$ and $>1$ indicate negative and positive allometric dependence with OM, respectively.

A hyperbolic function was used to model the growth trajectory of the various biomolecules and the RNA/DNA ratio. Larvae from all 3 studied months were integrated in the same model. Any structure is usually considered as full-grown when it has reached a size equalling $95 \%$ of its asymptotic value (Amenzoui et al. 2006). The hyperbolic functions were used to estimate: (1) the amount of any biomolecule and OM of the larvae at $95 \%$ of the asymptotic percentage; $(2)$ the larval SL that corresponds to this amount; and (3) the value at which the RNA/DNA ratio seems to stabilize along a given growth period. These functions were also used to estimate the biochemical composition of the first-feeding larvae, which are approximately $5 \mathrm{~mm}$ in length (Ré 1996).
Two different approaches were used to determine whether larvae were starved. First, RNA/DNA ratios were compared to the starvation value (1.3) defined by Chícharo (1997) for another clupeoid (Sardina pilchardus). Second, Clemmesen (1994) established an equation for Clupea harengus that relates the RNA/DNA ratios of starved larvae with their respective length-termed the starvation line (minimum RNA/DNA $=0.8883+0.0341 \mathrm{SL}$ ). Larvae with RNA/ DNA values below those predicted by the equation are considered to be starving. The $C$. harengus equation was applied here since the RNA/DNA ratio appears to have a minimum value necessary for survival that is independent of the species (Clemmesen 1994). The existence of a significant relationship between RNA/DNA ratio and SL was tested using linear regression. As proposed by Berdalet et al. (2005) and Caldarone et al. (2006), the RNA/DNA ratios were standardized to allow for a direct comparison of the results. The slope ratio of the calibration curves of Chícharo (1997) was DNA/RNA = 4.38 (A. Chícharo pers. comm.), that of Clemmesen (1994) was DNA/ RNA $=2.2$ (C. Clemmensen pers. comm.), and in the present study the ratio was DNA/RNA $=2.65$ $( \pm 0.025)$. Based on these values, the standardization factors comparing the present study to Chícharo (1997) and Clemmesen (1994) are 1.65 and 0.83, respectively. Therefore, the standardized starvation value of Chícharo would be 1.3:1.65 $=0.79$. RNA/DNA values obtained from the Clemmesen equation were similarly standardized: minimum RNA/ $\mathrm{DNA}=1.070+0.0411 \mathrm{SL}$.

\section{RESULTS}

\section{Environmental variables}

No significant differences (ANOVA $p>0.05$ ) in water temperature, salinity and density were found between months. Mean values were around $16^{\circ} \mathrm{C}$, had a salinity of 34.4 and a density of $25 \mathrm{~kg} \mathrm{~m}^{-3}$, respectively (Table 2).

\section{Size distribution of anchovy larvae}

The larval size distribution differed between months (Fig. 2). In June 2000, larvae of the smallest and the largest size classes were absent, and the distribution was skewed slightly towards preflexion size classes. In July 2000, larvae were the smallest, with most measuring below the mean size at notochord flexion. Finally, in June 2001, larvae were more evenly distributed among size classes, but preflexion 
Table 2. Temperature, salinity and density in each month (mean $\pm \mathrm{SD}$ ). Differences between months tested by ANOVA

\begin{tabular}{|lccc|}
\hline Month & $\begin{array}{c}\text { Temperature } \\
\left({ }^{\circ} \mathrm{C}\right)\end{array}$ & Salinity & $\begin{array}{c}\text { Sigma-t } \\
\left(\mathrm{kg} \mathrm{m}^{-3}\right)\end{array}$ \\
\hline June 2000 & $16.8 \pm 0.8$ & $34.4 \pm 0.4$ & $25.1 \pm 0.2$ \\
July 2000 & $17.0 \pm 0.6$ & $34.4 \pm 0.3$ & $25.4 \pm 0.4$ \\
June 2001 & $15.8 \pm 0.8$ & $34.4 \pm 0.1$ & $25.3 \pm 0.1$ \\
Differences & & & \\
$F$ & 2.53 & 0.01 & 0.67 \\
$\mathrm{p}$ & 0.1595 & 0.9915 & 0.5451 \\
\hline
\end{tabular}

larvae were more abundant than postflexion larvae. The percentage of notochord preflexion larvae was $60.6 \%$ in June 2000, 88.7 \% in July 2000 and $64.7 \%$ in June 2001.

\section{Ontogeny of biochemical composition}

Dry and OM weights showed an exponential relationship with SL with no significant differences between months (ANCOVA DW: slope $\mathrm{p}>0.10$, intercept $\mathrm{p}>0.78$; ANCOVA OM: slope $p>0.15$, intercept $p>0.90)$. Common equations were calculated for the $3 \mathrm{mo}(\mathrm{DW}=$ $0.0173 \mathrm{e}^{0.2984 \mathrm{SL}}, \mathrm{r}^{2}=0.913 ; \mathrm{OM}=0.0115 \mathrm{e}^{0.3077 \mathrm{SL}}, \mathrm{r}^{2}=0.798$; where DW and OM are in $\mathrm{mg}$ and SL in $\mathrm{mm}$ ).

\section{Composition of preflexion and postflexion larvae}

There was no significant month-stage interaction in the MANOVA examining Protein + Carbohydrate + Lipid content (PCL) (Wilk's $\lambda=0.77$, den df $=278, \mathrm{p}>$ 0.95), nor the MANOVA examining nucleic acid (DNA + RNA) content (NA) (Wilk's $\lambda=0.79$, den $\mathrm{df}=132, \mathrm{p}>$ $0.20)$. However, in both MANOVAs there were significant differences among months (PCL: Wilk's $\lambda=0.67$, den $\mathrm{df}=196, \mathrm{p}<0.0001$; NA: Wilk's $\lambda=0.80$, den $\mathrm{df}=$ 132, $\mathrm{p}<0.006$ ) and stages (PCL: Wilk's $\lambda=0.12$, den $\mathrm{df}=239, \mathrm{p}<0.0001$; NA: Wilk's $\lambda=0.60$, den $\mathrm{df}=132$, $\mathrm{p}<0.0001$ ). These differences in biochemical composition appeared to be primarily between larvae in the 2 smaller size classes ( $\mathrm{SL}<7.5 \mathrm{~mm}$ and the $7.5 \mathrm{~mm} \leq$ $\mathrm{SL}<9.5 \mathrm{~mm}$ ) and larvae in the 2 larger size classes (9.5 $\mathrm{mm} \leq \mathrm{SL}<11.5 \mathrm{~mm}$ and $\mathrm{SL} \geq 11.5 \mathrm{~mm}$ stages) (based on Tukey post-hoc tests). The differences among months were mostly between July 2000 and June 2000/2001.

Proteins were always the major biochemical constituent of OM, whereas DNA was the minor constituent (Table 3). As larvae grew from preflexion to postflexion stages, there was an increase in protein and RNA relative contents and a decrease in carbohydrate and lipid relative contents. DNA relative con- tent was nearly constant during the 4 defined stages (Table 3). Larvae collected in July 2000 differed more from the other 2 months in terms of biochemical composition. In the preflexion stages, the PCL + NA was higher in July 2000 than in both June 2000 and June 2001, but lower in the postflexion stages (Table 4). Of all stages, larvae from July 2000 had the lowest P\% and the lowest RNA/DNA ratios, and proteins contributed less and DNA contributed more to the overall increase in OM. The calculated RNA/DNA ratio was much lower in the preflexion stages in July 2000 (1.7) than in June 2000 and 2001 (2.8). However, the ratio in July 2000 (3.1) reached nearly the same value as June 2000 and June 2001 (3.5) in the postflexion stages. The protein/DNA ratio increased with larval stage over the $3 \mathrm{mo}$, but the overall values and the total increment during growth were higher in both June 2000 and June 2001 (from 40.1 to 46.6) than in July 2000 (from 25.4 to 26.8). The mean contribution of each biomolecule to the total increment in OM was $\sim 67.2 \%$ for proteins, $\sim 20.5 \%$ for lipids, $\sim 6.2 \%$ for RNA $\%, \sim 4.2 \%$ for carbohydrates, and finally $\sim 1.8 \%$ for DNA (Table 3 ).

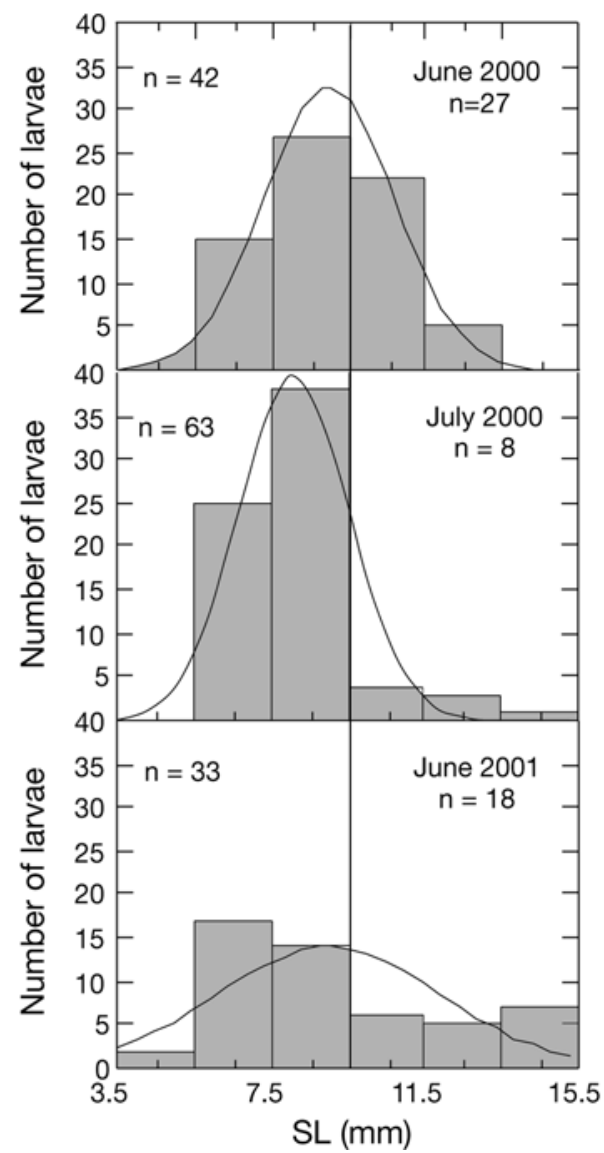

Fig. 2. Engraulis encrasicolus. Frequency distribution of larvae. SL: standard length. Vertical line shows the mean size of notochord flexion. Number of larvae before and after notochord flexion is indicated 


\section{Allometric relationships of biomolecules with OM}

An ANCOVA of the initial linear regressions relating biomolecules to OM between months (Table 5) showed that the intercepts of these regressions were significantly different in all the biomolecules, except for RNA. However, there were no significant differences in the slopes of proteins, carbohydrates or DNA. Therefore, 3 regression equations with equal slopes but different intercepts were used to relate proteins, carbohydrates and DNA to OM for each biomolecule, and another 3 equations, with equal intercepts but different slopes, were used to relate RNA to OM (Table 6). For lipids, each month had a separate equation.

The allometric relationships were different among biomolecules, but consistent among months for each biomolecule. RNA showed a clear positive allometry relative to OM (slope $=1.208$ to 1.217 ). Protein and DNA exhibited slightly positive allometries (slope = 1.082 , slope $=1.037$, respectively). Carbohydrates and lipids showed negative allometries (slope $=0.799$, slope $=0.646$ to 0.988 , respectively) .

Table 3. Engraulis encrasicolus. Modeled biochemical composition (mean $\pm \mathrm{SD}$ ) of larvae by stage-class and month (see explanation in 'Data treatment' section). Weight gain: increment in weight content and in the percentage of the total weight increment in organic matter $(\mathrm{OM})$ that corresponds to each biomolecule during larval growth from standard length (SL) $<7.5$ to SL $\geq$ $11.5 \mathrm{~mm}$. Where the Tukey post hoc test did not find significant differences between stages or between months, the mean composition for each size-class or month was calculated

\begin{tabular}{|c|c|c|c|c|c|c|c|}
\hline Stage-class & Month & $\begin{array}{l}\text { Dry weight } \\
\left(\mu \mathrm{g} \text { larva }^{-1}\right)\end{array}$ & $\begin{array}{c}\text { Fraction } \\
(\%)\end{array}$ & Stage-class & Month & $\begin{array}{l}\text { Dry weight } \\
\left(\mu g \text { larva }^{-1}\right)\end{array}$ & $\begin{array}{c}\text { Fraction } \\
(\%)\end{array}$ \\
\hline Proteins & & & & & July 2000 & $58.4 \pm 22.0$ & $21.8 \pm 8.2$ \\
\hline \multirow{3}{*}{$\mathrm{SL}<7.5$} & June 2000 & $56.5 \pm 7.5$ & $61.7 \pm 8.2$ & & June 2001 & $58.4 \pm 22.0$ & $21.8 \pm 8.2$ \\
\hline & July 2000 & $56.7 \pm 5.8$ & $57.9 \pm 5.9$ & $\mathrm{SL} \geq 11.5$ & June 2000 & $110.6 \pm 31.8$ & $20.5 \pm 5.9$ \\
\hline & June 2001 & $56.5 \pm 7.5$ & $61.7 \pm 8.2$ & & July 2000 & $138.7 \pm 52.2$ & $21.8 \pm 8.2$ \\
\hline \multirow[t]{3}{*}{$7.5 \leq \mathrm{SL}<9.5$} & June 2000 & $97.0 \pm 12.9$ & $61.7 \pm 8.2$ & & June 2001 & $138.7 \pm 52.2$ & $21.8 \pm 8.2$ \\
\hline & July 2000 & $88.0 \pm 9.0$ & $57.9 \pm 5.9$ & Weight gain & June 2000 & 88.9 & 20.3 \\
\hline & June 2001 & $97.0 \pm 12.9$ & $61.7 \pm 8.2$ & & July 2000 & 112.1 & 20.6 \\
\hline \multirow[t]{3}{*}{$9.5 \leq \mathrm{SL}<11.5$} & June 2000 & $189.6 \pm 20.4$ & $67.8 \pm 7.3$ & & June 2001 & 112.1 & 20.6 \\
\hline & July 2000 & $163.2 \pm 26.1$ & $62.6 \pm 10.0$ & DNA & & & \\
\hline & June 2001 & $189.6 \pm 20.4$ & $67.8 \pm 7.3$ & $\mathrm{SL}<7.5$ & June 2000 & $1.4 \pm 0.4$ & $1.6 \pm 0.4$ \\
\hline \multirow[t]{3}{*}{$\mathrm{SL} \geq 11.5$} & June 2000 & $424.6 \pm 45.7$ & $67.8 \pm 7.3$ & & July 2000 & $2.2 \pm 0.7$ & $2.3 \pm 0.7$ \\
\hline & July 2000 & $279.6 \pm 44.7$ & $62.6 \pm 10.0$ & & June 2001 & $1.4 \pm 0.4$ & $1.6 \pm 0.4$ \\
\hline & June 2001 & $424.6 \pm 45.7$ & $67.8 \pm 7.3$ & $7.5 \leq \mathrm{SL}<9.5$ & June 2000 & $2.3 \pm 0.6$ & $1.6 \pm 0.4$ \\
\hline \multirow[t]{3}{*}{ Weight gain } & June 2000 & 368.2 & 68.8 & & July 2000 & $3.4 \pm 1.0$ & $2.3 \pm 0.7$ \\
\hline & July 2000 & 222.9 & 63.9 & & June 2001 & $2.3 \pm 0.6$ & $1.6 \pm 0.4$ \\
\hline & June 2001 & 368.2 & 68.8 & $9.5 \leq \mathrm{SL}<11.5$ & June 2000 & $4.7 \pm 1.2$ & $1.6 \pm 0.4$ \\
\hline Carbohydrates & & & & & July 2000 & $7.4 \pm 2.3$ & $2.3 \pm 0.7$ \\
\hline \multirow{3}{*}{$\mathrm{SL}<7.5$} & June 2000 & $8.6 \pm 5.7$ & $8.5 \pm 5.6$ & & June 2001 & $4.7 \pm 1.2$ & $1.6 \pm 0.4$ \\
\hline & July 2000 & $9.2 \pm 0.9$ & $9.4 \pm 0.9$ & $\mathrm{SL} \geq 11.5$ & June 2000 & $9.1 \pm 2.3$ & $1.6 \pm 0.4$ \\
\hline & June 2001 & $2.9 \pm 1.4$ & $3.5 \pm 1.7$ & & July 2000 & $10.4 \pm 3.2$ & $2.3 \pm 0.7$ \\
\hline \multirow[t]{3}{*}{$7.5 \leq \mathrm{SL}<9.5$} & June 2000 & $13.8 \pm 9.1$ & $8.5 \pm 5.6$ & & June 2001 & $9.1 \pm 2.3$ & $1.6 \pm 0.4$ \\
\hline & July 2000 & $14.3 \pm 1.4$ & $9.4 \pm 0.9$ & Weight gain & June 2000 & 7.7 & 1.6 \\
\hline & June 2001 & $5.2 \pm 2.5$ & $3.5 \pm 1.7$ & & July 2000 & 8.2 & 2.3 \\
\hline \multirow[t]{3}{*}{$9.5 \leq \mathrm{SL}<11.5$} & June 2000 & $16.8 \pm 11.2$ & $6.0 \pm 4.0$ & & June 2001 & 7.7 & 1.6 \\
\hline & July 2000 & $15.4 \pm 5.5$ & $5.9 \pm 2.1$ & RNA & & & \\
\hline & June 2001 & $6.4 \pm 3.1$ & $2.3 \pm 1.1$ & $\mathrm{SL}<7.5$ & June 2000 & $3.9 \pm 1.0$ & $4.3 \pm 1.1$ \\
\hline \multirow[t]{3}{*}{$\mathrm{SL} \geq 11.5$} & June 2000 & $32.4 \pm 21.6$ & $6.0 \pm 4.0$ & $\mathrm{SL}<T . \mathrm{J}$ & July 2000 & $3.9 \pm 1.0$ & $4.3 \pm 1.1$ \\
\hline & July 2000 & $26.4 \pm 9.4$ & $5.9 \pm 2.1$ & & June 2001 & $3.9 \pm 1.0$ & $4.3 \pm 1.1$ \\
\hline & June 2001 & $15.3 \pm 7.3$ & $2.3 \pm 1.1$ & $7.5 \leq \mathrm{SL}<9.5$ & June 2000 & $6.3 \pm 1.6$ & $4.3 \pm 1.1$ \\
\hline \multirow[t]{3}{*}{ Weight gain } & June 2000 & 23.7 & 5.4 & & July 2000 & $6.3 \pm 1.6$ & $4.3 \pm 1.1$ \\
\hline & July 2000 & 17.1 & 4.9 & & June 2001 & $6.3 \pm 1.6$ & $4.3 \pm 1.1$ \\
\hline & June 2001 & 12.4 & 2.1 & $9.5 \leq \mathrm{SL}<11.5$ & June 2000 & $17.5 \pm 3.5$ & $5.9 \pm 1.2$ \\
\hline Lipids & & & & & July 2000 & $17.5 \pm 3.5$ & $5.9 \pm 1.2$ \\
\hline \multirow[t]{3}{*}{$\mathrm{SL}<7.5$} & June 2000 & $21.7 \pm 5.0$ & $21.4 \pm 4.9$ & & June 2001 & $17.5 \pm 3.5$ & $5.9 \pm 1.2$ \\
\hline & July 2000 & $26.7 \pm 6.4$ & $28.6 \pm 6.9$ & $\mathrm{SL} \geq 11.5$ & June 2000 & $32.1 \pm 6.8$ & $5.9 \pm 1.2$ \\
\hline & June 2001 & $26.7 \pm 6.4$ & $28.6 \pm 6.9$ & & July 2000 & $32.1 \pm 6.8$ & $5.9 \pm 1.2$ \\
\hline \multirow[t]{3}{*}{$7.5 \leq \mathrm{SL}<9.5$} & June 2000 & $34.7 \pm 7.9$ & $21.4 \pm 4.9$ & & June 2001 & $32.1 \pm 6.8$ & $5.9 \pm 1.2$ \\
\hline & July 2000 & $43.2 \pm 10.4$ & $28.6 \pm 6.9$ & Weight gain & June 2000 & 28.2 & 6.2 \\
\hline & June 2001 & $43.2 \pm 10.4$ & $28.6 \pm 6.9$ & & July 2000 & 28.2 & 6.2 \\
\hline $9.5 \leq \mathrm{SL}<11.5$ & June 2000 & $57.4 \pm 16.5$ & $20.5 \pm 5.9$ & & June 2001 & 28.2 & 6.2 \\
\hline
\end{tabular}


Table 4. Engraulis encrasicolus. Modeled PCL + NA content, and RNA/DNA and protein/DNA ratios of larvae by stageclass and month (see explanation in 'Data treatment' section). PCL + NA is the sum of modeled weights of proteins, carbohydrates, lipids, DNA and RNA

\begin{tabular}{|llccc|}
\hline Stage-class & Month & $\begin{array}{c}\text { PCL + NA } \\
\left(\text { g larva }^{-1}\right)\end{array}$ & $\begin{array}{c}\text { RNA/ } \\
\text { DNA }\end{array}$ & $\begin{array}{c}\text { Protein/ } \\
\text { DNA }\end{array}$ \\
\hline SL $<7.5$ & June 2000 & 92.1 & 2.8 & 40.1 \\
& July 2000 & 98.8 & 1.7 & 25.4 \\
$7.5 \leq \mathrm{SL}<9.5$ & June 2001 & 91.3 & 2.8 & 40.1 \\
& June 2000 & 154.0 & 2.7 & 41.9 \\
& July 2000 & 155.1 & 1.8 & 25.7 \\
\multirow{5}{*}{$9.5 \leq \mathrm{SL}<11.5$} & June 2001 & 154.0 & 2.7 & 41.9 \\
& June 2000 & 286.0 & 3.7 & 40.5 \\
& July 2000 & 261.9 & 2.4 & 22.0 \\
SL $\geq 11.5$ & June 2001 & 276.6 & 3.7 & 40.5 \\
& June 2000 & 608.8 & 3.5 & 46.6 \\
& July 2000 & 487.2 & 3.1 & 26.8 \\
Weight gain & June 2001 & 619.8 & 3.5 & 46.6 \\
& June 2000 & 516.7 & & \\
& July 2000 & 388.8 & & \\
& June 2001 & 528.5 & & \\
\hline
\end{tabular}

Relative importance of each biomolecule and change in the RNA/DNA ratio in relation to OM

A rectangular hyperbola - an asymptotic function best described the relationship between the percentage of a biochemical component and the total OM content of that larva (Figs. $3 \& 4$ ). The relationship between $\mathrm{P} \%$ and $\mathrm{OM}$ was initially positive and became asymptotic when $\mathrm{P} \%$ reached $71.2 \%$. In contrast, $\mathrm{CH}$ and $\mathrm{L}$ relative contents decreased as OM increased and they became constant at 5.6 and 20.2\% of OM, respectively (Fig. 3). The relationship between the RNA/DNA ratio and OM content became asymptotic at a value of 3.6 (Fig. 4).

The back-calculated sizes at which the larvae reached $95 \%$ of the asymptotic values clustered into a very narrow length range between 11.6 and $12.4 \mathrm{~mm}$, and an OM content between 438 and $546 \mu \mathrm{g}$ (Table 7). The biochemical composition of a first-feeding, $5 \mathrm{~mm}$ long anchovy larva, modeled according to the equations relating biomolecule percentage to OM, was $49.8 \%$ proteins, $12.6 \%$ carbohydrates and $41.2 \%$ lipids (Table 7 ).

\section{Starvation}

According to the standardized starvation value defined by Chícharo (1997), none of the larvae analysed in this work
Table 5. Engraulis encrasicolus. ANCOVAs to test the effect of month on biomolecule content (log ng larva ${ }^{-1}$ ) with organic matter (OM) (log OM ng larva ${ }^{-1}$ ) as a covariate. $\mathrm{CH}$ : carbohydrates

\begin{tabular}{|lrrcc|}
\hline \multirow{2}{*}{ Biomolecule } & \multicolumn{2}{c}{ Intercept } & \multicolumn{2}{c|}{ Slope } \\
& $F$ & $\mathrm{p}$ & $F$ & $\mathrm{p}$ \\
\hline Proteins & 5.68 & 0.0045 & 2.91 & 0.0587 \\
CH & 16.70 & $<0.0001$ & 0.15 & 0.8643 \\
Lipids & 7.82 & 0.0007 & 4.96 & 0.0087 \\
DNA & 17.29 & $<0.0001$ & 2.29 & 0.1081 \\
RNA & 2.01 & 0.1407 & 3.24 & 0.0450 \\
\hline
\end{tabular}

was starved (Fig. 5). As the RNA/DNA ratio was positively related to length in June and July 2000 (June 2000: RNA/DNA $=1.819+0.2 \mathrm{SL}, \mathrm{r}^{2}=0.158, \mathrm{p}<0.03$; July 2000: RNA/DNA $=0.314+0.199 \mathrm{SL}, \mathrm{r}^{2}=0.400, \mathrm{p}<$ 0.002, where SL is in $\mathrm{mm}$ ) (Fig. 5), the starvation line defined by Clemmesen (1994), which takes into account the relationship between RNA/DNA and SL, was also used. Only one larva from July 2000 was below this line (Fig. 5), and thus starved, according to Clemmesen (1994).

\section{DISCUSSION}

\section{Ontogeny of biochemical composition}

Changes in the biochemical composition of Engraulis encrasicolus larvae were dominated by ontogenetic trends. The DW-SL relationship for larval E. encrasicolus is best defined by the exponential function DW =

Table 6. Engraulis encrasicolus. Equations calculated using common slopes and intercepts when no significant differences were found between months on biomolecule content (log ng larva ${ }^{-1}$ ) with organic matter (OM) (log OM ng larva ${ }^{-1}$ ) as a covariate (see Table 5). Prot: proteins; $\mathrm{CH}$ : carbohydrates; Lip: lipids; CI: slope's 95\% confidence interval. Note: all of the regressions had $\mathrm{p}<0.0001$

\begin{tabular}{|llcc|}
\hline Month & \multicolumn{1}{c}{ Equation } & CI slope & $\mathrm{r}^{2}$ \\
\hline June 2000 & $\log$ Prot $=1.082 \log \mathrm{OM}-0.623$ & $1.044-1.121$ & 0.970 \\
& $\log \mathrm{CH}=0.799 \log \mathrm{OM}-0.270$ & $0.529-1.070$ & 0.333 \\
& $\log \mathrm{Lip}=0.890 \log \mathrm{OM}-0.100$ & $0.723-1.057$ & 0.759 \\
& $\log \mathrm{DNA}=1.037 \log \mathrm{OM}-2.047$ & $0.938-1.136$ & 0.860 \\
July 2000 & $\log \mathrm{RNA}=1.217 \log \mathrm{OM}-2.448$ & $1.132-1.303$ & 0.915 \\
& $\log$ Prot $=1.082 \log \mathrm{OM}-0.659$ & $1.044-1.121$ & 0.970 \\
& $\log \mathrm{CH}=0.799 \log \mathrm{OM}-0.017$ & $0.529-1.070$ & 0.333 \\
& $\log \mathrm{Lip}=0.988 \log \mathrm{OM}-0.521$ & $0.773-1.203$ & 0.649 \\
& $\log \mathrm{DNA}=1.037 \log \mathrm{OM}-1.844$ & $0.938-1.136$ & 0.860 \\
June 2001 & $\log \mathrm{RNA}=1.208 \log \mathrm{OM}-2.448$ & $1.123-1.294$ & 0.915 \\
& $\log$ Prot $=1.082 \log \mathrm{OM}-0.645$ & $1.044-1.121$ & 0.970 \\
& $\log \mathrm{CH}=0.799 \log \mathrm{OM}-0.521$ & $0.529-1.070$ & 0.333 \\
& $\log \mathrm{Lip}=0.646 \log \mathrm{OM}+1.291$ & $0.523-0.770$ & 0.809 \\
& $\log \mathrm{DNA}=1.037 \log \mathrm{OM}-1.982$ & $0.938-1.136$ & 0.860 \\
& $\log \mathrm{RNA}=1.207 \log \mathrm{OM}-2.448$ & $1.122-1.291$ & 0.915 \\
\hline
\end{tabular}




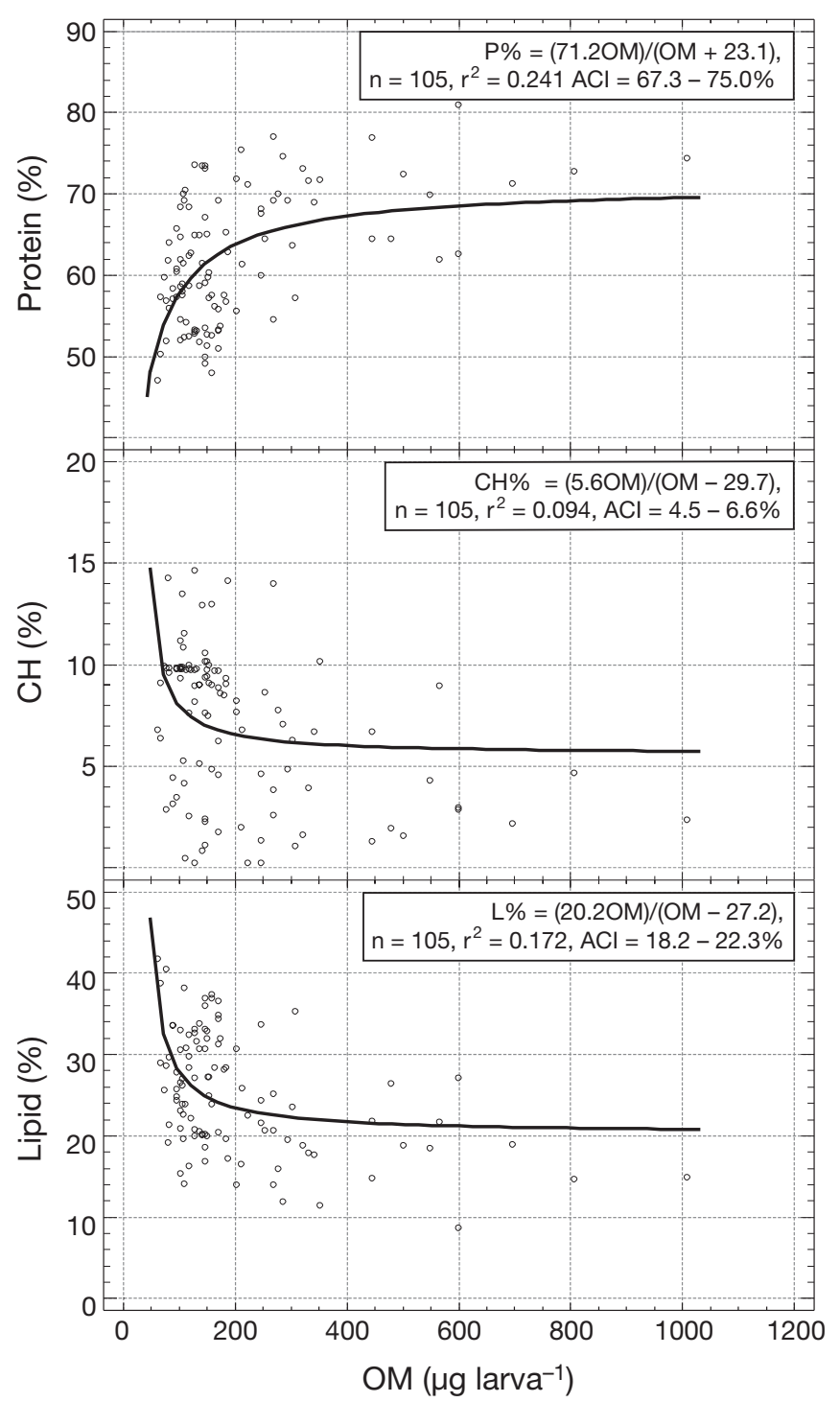

Fig. 3. Engraulis encrasicolus. Relationship of the percentage (relative content) of each biomolecule with the organic matter (OM) content of larvae (see explanation in 'Data treatment' section). P: protein; $\mathrm{CH}$ : carbohydrate; L: lipid; ACI: asym potic $95 \%$ confidence interval

$0.0173 \mathrm{e}^{0.2984 \mathrm{SL}}$. Rossi et al. (2006) found a very similar relationship in E. encrasicolus from the Mediterranean Sea $\left(\mathrm{DW}=0.02 \mathrm{e}^{0.30 \mathrm{SL}}\right)$. In other studies, power equations provided the best fit for the relationship between these 2 parameters (García et al. 2003, Estensoro 2006). This discrepancy between the forms of the best equation could be explained by the different length range of the individuals analysed in the different studies.

Proteins were the main organic component in anchovy larvae, followed by lipids and, finally, carbohydrates. This has been observed in other studies of Engraulis encrasicolus (Guisande et al. 1998) and in

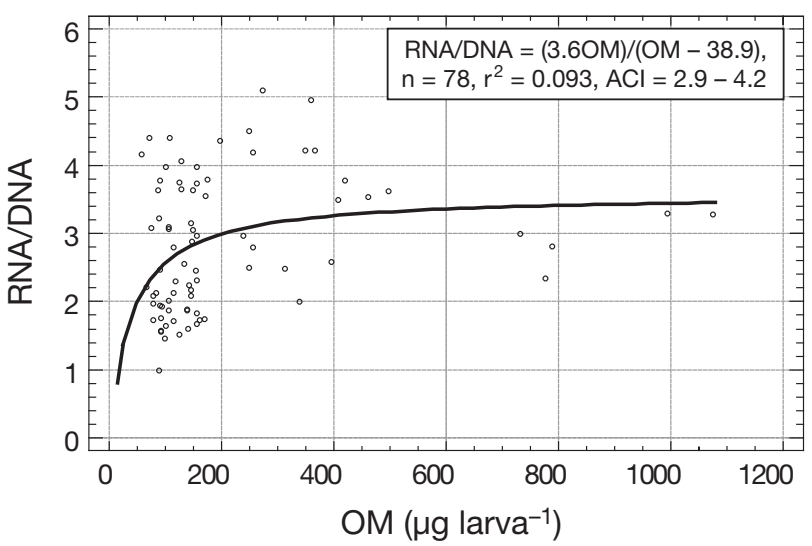

Fig. 4. Engraulis encrasicolus. Relationship of the RNA/DNA ratio with the organic matter (OM) content of larvae (see explanation in 'Data treatment' section). ACI: asympotic $95 \%$ confidence interval

studies of other fish larvae (Ehrlich 1974a,b, Cetta \& Capuzzo 1982). However, the mean carbohydrate content established in the present study ( 2.3 to $8.5 \%$ of OM) was lower than that reported for anchovy by Guisande et al. (1998) (mean $=16.5 \%$ of PCL), but was very similar to that obtained for herring (3.4 to $4.6 \%$ of DW), another clupeoid (Ehrlich 1975).

The trends obtained for each biomolecule using the 3 different approaches were almost the same: the relative content of proteins and RNA increased, while DNA was almost constant and carbohydrates and lipids decreased with larval size. Protein synthesis and accumulation must be one of the main priorities in a growing larva. The importance of carbohydrates as an energy source may lessen throughout development until they fulfil a predominantly structural role in the anchovy larvae (Heming \& Buddington 1988). Lipid depletion occurs as a consequence of using stored lipids for energy in a non-feeding larva, which may explain the decreasing relative importance of lipids as a constituent of OM. However, the rapid accumulation of proteins may be the main factor leading to the relative decrease in lipid content in anchovy larvae. The constant relative DNA content during growth indicates that larvae mainly grew as a consequence of cell multiplication or hyperplasia.

Cells of preflexion larvae were less metabolically active than those of postflexion larvae. Relative RNA content increased with size and exhibited a clearly positive allometric relationship with larval OM content. The relative DNA content was nearly constant and its relationship with OM was almost isometric. Thus, there was an increase in the RNA/DNA ratios from preflexion to postflexion larvae (Table 4), indicating that larger larvae have a higher protein synthesis capability than smaller larvae. 
The trends in biomolecules in anchovy (present study and Guisande et al. 1998) confirm the increase in relative protein content and the decrease in relative lipid content during larval development, as observed in other species (Ehrlich 1974a,b, Cetta \& Capuzzo 1982). However, even though the relative contribution of lipids decreased during growth, this group of biomolecules was ranked second in terms of contribution to larval OM weight gain: proteins account for about $67 \%$ and lipids for about $20 \%$ of the increase (Table 3). The apparent contradiction of the accumulation of lipids and the relative decrease in lipids is explained by a 7 -fold increase in protein content compared to a 5 -fold increase in lipid content from preflexion to postflexion larvae (Table 3).

This relative increase in proteins and the relative decrease in lipids with size in Engraulis encrasicolus larvae fits with the definition given by Pfeiler (1986) of 'Type 1 larvae'. In Type 1 larvae, which are representative of most fish species, increases in somatic mass are accomplished primarily by accumulation of proteins in the form of muscle. The overall strategy of the Type 1 larva is summarized as: (1) maximize growth and minimize the duration of the larval phase; (2) shorten the time spent in size-classes that are more vulnerable to predation (Folkvord \& Hunter 1986); and (3) increase locomotive capabilities, thereby increasing the prey spectrum (Blaxter \& Hempel 1963). This strategy of early positive allometric growth in the morpho-functional systems involved in swimming and feeding, followed by more isometric growth, matches that found in the common carp (Osse et al. 1997). Although growth of the morpho-functional systems has not been examined for E. encrasicolus, Dulčić (1997) found that the maximum growth in length occurred at $14.3 \mathrm{~mm}$, which corresponds to a postflexion larva and is close to the length at which larvae reached $95 \%$ of the asymptotic value of optimal proportion of biomolecules (Table 7).

The asymptotic percentage values predicted for the 3 biochemical constituents by the models may suggest that the proportion of each biochemical component in Engraulis encrasicolus larvae would tend to stabilize

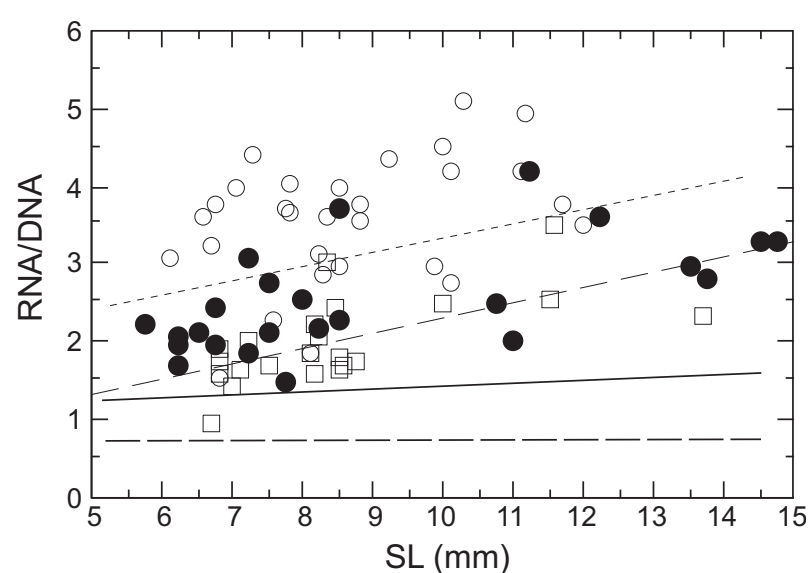

Fig. 5. Engraulis encrasicolus. Relationship of RNA/DNA ratio with standard length (SL). (- -O- -) June 2000, (- $\square-$ ) July 2000, (@) June 2001, (一) Clemmesen's starvation line (Clemmesen 1994), (- -) Chícharo's starvation value (Chícharo 1997)

at a given value to maximize growth and, therefore, to optimize larval survival and fitness. Once every biochemical component has reached its asymptotic percentage value - its 'optimal proportion' - each component is accreted in these proportions (see also Cetta \& Capuzzo 1982), which is a result of the respective trade-offs between energy allocated to growth, to predation avoidance and to storage (Post \& Parkinson 2001). The 'optimal proportions' will likely change during ontogeny because the trade-offs between growth, predation, and energy storage change. According to Post \& Parkinson (2001), small anchovy larvae may invest energy into growing more rapidly, while energy storage is low. Once larvae develop all the anatomical characteristics needed for efficient swimming, they are better able to escape predators and to find and capture prey. Consequently, more resources can be allocated to energy storage, most likely in the form of lipids. These reserves may be critical when the larva reaches metamorphosis, because the changes in morphology, physiology and behaviour linked to metamorphosis consume a high amount of lipids (Nursall 1989). Ehrlich (1974b) observed such a shift in biomolecule

Table 7. Engraulis encrasicolus. (A) Calculation of the mean $( \pm \mathrm{SD})$ organic matter $(\mathrm{OM})$ content and standard length (SL) at which larvae reach $95 \%$ of the asymptotic value of each biomolecule. (B) Estimated composition of a first-feeding $5 \mathrm{~mm}$ and $53.6 \mu \mathrm{g}$ OM larva. To transform OM content into SL, the following equation was used: $\mathrm{SL}=\ln [(\mathrm{OM} / 0.0115) / 0.3077]$. P\%: protein percentage in $\mathrm{OM}_{i} \mathrm{CH} \%$ : carbohydrate percentage in $\mathrm{OM}_{i} \mathrm{~L} \%$ : lipid percentage in $\mathrm{OM}$

\begin{tabular}{|c|c|c|c|c|c|}
\hline \multirow{2}{*}{ Function } & \multicolumn{3}{|c|}{ A } & \multirow{2}{*}{$\begin{array}{l}\text { Modeled rel. biomole- } \\
\text { cule content (\%) }\end{array}$} & \multirow[b]{2}{*}{ 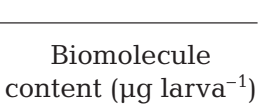 } \\
\hline & $\begin{array}{l}\text { Rel. biomolecule } \\
\text { content }(\%)\end{array}$ & $\begin{array}{l}\text { OM content } \\
\left(\mu g \text { larva }^{-1}\right)\end{array}$ & $\begin{array}{c}\mathrm{SL} \\
(\mathrm{mm})\end{array}$ & & \\
\hline $\mathrm{P} \%=(71.2 \mathrm{OM}) /(\mathrm{OM}+23.1)$ & $67.6 \pm 3.7$ & $438.0 \pm 172.0$ & $11.6 \pm 1.4$ & 49.8 & 26.7 \\
\hline $\mathrm{CH} \%=(5.6 \mathrm{OM}) /(\mathrm{OM}-29.7)$ & $5.8 \pm 1.1$ & $598.0 \pm 298.0$ & $12.4 \pm 1.8$ & 12.6 & 6.7 \\
\hline $\mathrm{L} \%=(20.2 \mathrm{OM}) /(\mathrm{OM}-27.2)$ & $21.4 \pm 2.2$ & $546.0 \pm 170.0$ & $12.4 \pm 1.1$ & 41.2 & 22.1 \\
\hline
\end{tabular}


accumulation in herring, where larvae $<20 \mathrm{~mm}$ deposited proteins faster than lipids, but larvae $>20 \mathrm{~mm}$ deposited lipids faster than proteins.

\section{Temporal comparison of biochemical composition}

The biochemical composition of larvae from July 2000 was very different from those captured in June 2000 and 2001, and larval development in July 2000 was delayed. Food availability does not seem to be responsible, as the concentration and quality of food did not differ between July 2000 and June 2000 and 2001 (Díaz et al. 2007). Furthermore, the feeding incidence of larvae from July 2000 was not significantly different to that of the other months (L. Intxausti unpubl. data). The average temperature was not significantly different among months (Díaz et al. 2007), and even if the change in surface temperature is considered, growth rates in anchovy are higher at higher temperatures (Palomera et al. 1988), so temperature cannot explain the lower relative protein content of larvae captured in July 2000. A possible explanation is a parental effect, which could have caused differences in offspring size and biochemical composition (Høie et al. 1999, Riveiro et al. 2000). Riveiro et al. (2000) found in Sardina pilchardus that larval survival time extended as the percentage of protein in the egg, which is determined by the parents, increased. Larvae hatched from eggs with originally higher relative protein content may need less time to reach the asymptotic value of protein percentage and, therefore, spend less time in the size-classes more vulnerable to predation and starvation. The smallest larvae from July 2000 had the lowest relative protein content of all the individuals from the 3 mo sampled during that year. This could reflect an initially bad condition of the eggs but, as there is no data on parental status or egg composition, it is not possible to address this hypothesis with respect to anchovy larvae from July 2000, June 2000, and June 2001. To evaluate the differences between initial condition and larval development over time, it would be necessary to examine food availability, temperature, and parental contribution in more detail, while simultaneously undertaking a detailed biochemical assessment of the larvae.

\section{Condition of larvae}

The range and the asymptotic relationship of the RNA/DNA ratios of Engraulis encrasicolus larvae in the present study agree with previous studies. Our RNA/DNA ratio (1.7 to 4.5$)$ embraces the range obtained by García et al. (2005) (2.4 to 3.9), and the values are directly comparable (see Caldarone et al. 2006), since the DNA/RNA ratio of the slopes of the calibration curves are nearly the same (García et al. $2005=2.5$, D. Cortés pers. comm, present study $=2.65$ ). The asymptotic relationship of the RNA/DNA ratio with size in our study (Fig. 4) agrees with the asymptotic growth pattern found in the clupeoid Sardinops melanostictus (Watanabe \& Kuroki 1997).

The asymptotic relationship between RNA/DNA ratio and size matches the hypothesis of Pepin et al. (1999), which suggests that RNA/DNA and growth rate are indicators of survival probability and that, as a population gets older, their values contract towards higher values. In this study we have shown that in addition to this, the biomolecules contract towards an optimal proportion. When this higher RNA/DNA ratio or optimal biomolecule proportion is approached, the variability in biochemical composition and growth rate decreases. It is likely that the RNA/DNA ratio and the proportion of biomolecules depend on environmental conditions, but when approaching the 'optimal proportion' of biomolecules or the optimal RNA/DNA ratio, physiological mechanisms dealing with larval homeostasis, homeokinesis and rheostasis would tend to dampen environmentally induced changes.

To interpret the physiological meaning of a determinate RNA/DNA value, it is necessary to know at what sizes and values the relationship of RNA/DNA with OM becomes asymptotic. Knowledge of multiple 'sizes' and 'values' is necessary because different combinations of temperatures and prey levels will result in different asymptotic relationships (Buckley 1984, Ferron \& Legget 1994). We hypothesize that, as optimal combinations of food and temperature are approached, the asymptotic value of RNA/DNA will increase, and ultimately be limited by cell biochemistry. This maximum asymptotic RNA/DNA value would be the optimal nucleic acid proportion and would theoretically make non-limited larval growth possible and might maximize the probability of larval survival. Actual RNA/DNA values found in a given larval population, when compared with starving RNA/DNA values (described above) and the asymptotic maximum RNA/DNA value, could be used to determine the overall status of the population. This approach would allow the determination of overall well-being of the population, and not only its nutritional status.

The asymptotic relationship between RNA/DNA and OM may explain why some studies have found positive relationships of RNA/DNA with size (García et al. 1998, Ramírez et al. 2001), while others find no relationship (Ramírez et al. 2004, Catalán et al. 2006). Supporting this theory, García et al. (2006) found that RNA/DNA ratios did not increase with SL in late larval stages of Sardina pilchardus. According to this, an 
upper limit in larval condition or RNA/DNA ratio is reached at a certain size - at the asymptotic value after which, despite further increase in size, larval condition or RNA/DNA ratio remain fairly constant (Pepin et al. 1999, García et al. 2006).

The effects of temperature and food on the RNA/DNA ratio and the condition of Engraulis encrasicolus larvae are difficult to assess from the results of this study. Specifically designed laboratory experiments, in which the effects of temperature and food can be isolated from other variables, would be necessary. As far as we know, those experiments have not been undertaken in E. encrasicolus. In our study, the average temperature was not significantly different between the sampled months, so the effect of temperature could not be tested. Concerning food, the rarity of starved larvae may suggest an adequate nutritional environment on the Basque continental shelf during the anchovy spawning period in 2000 and 2001 (Díaz et al. 2007). Alternatively, larvae in poor or intermediate condition may be selectively removed from the population as a consequence of being more vulnerable to predation (Buckley \& Lough 1987). In either case, the observation of few starving larvae is consistent with other studies in the region (Chícharo et al. 1998a,b) and with studies from other regions (Ferron \& Legget 1994). Additionally, some studies have analyzed the nutritional environment for fish larvae in Atlantic waters North of Spain during the spring-summer period, and have concluded that food was not limiting in this area (Chícharo et al. 1998b, Díaz et al. 2007).

\section{CONCLUSIONS}

Changes in the biochemical composition of Engraulis encrasicolus larvae in the Bay of Biscay during the spawning periods in 2000 and 2001 (late spring-early summer) are primarily related to ontogenetic development. These changes maximize efficiency in larval growth and improve overall survival fitness as a whole. However, environmentally induced changes in biochemical composition and variability in parental contribution might alter the ontogenetically constrained general trends and, as a result, cause variability in larval growth and survival. To resolve these issues, new studies aimed at relating biochemical parameters to larval growth are required. Both kinds of data, those based on field observations from different seasons or places, including adults and larvae, as well as those derived from laboratory experiments performed under controlled conditions, are needed to reveal details on the causes of variability in the biochemical composition of E. encrasicolus larvae.
Acknowledgements. E.D. was supported by a grant from the Department of Education, Universities and Research of the Basque Government, and the study by the Spanish Ministry of Science and Technology (MAR1999-0328-C03-02). We are grateful to M. Collins from the University of Southampton and AZTI-Tecnalia and to Prof. M. M. Ortega from the University of the Basque Country for the language revision of the manuscript, to Drs. Clemmesen, Chícharo and Cortés for kindly giving us their D/R slope values, and to 2 anonymous referees for their useful comments. This paper is contribution no. 394 from AZTI-Tecnalia (Marine Research).

\section{LITERATURE CITED}

Amenzoui K, Ferhan-Tachinante F, Yahyaoui A, Kifani S, Mesfioui A (2006) Analysis of the cycle of reproduction of Sardina pilchardus (Walbaum, 1792) off the Moroccan Atlantic coast. C R Biol 329:892-901

Bailey KM, Houde ED (1989) Predation on eggs and larvae of marine fishes and the recruitment problem. Adv Mar Biol 25:1-83

Belchier M, Clemmesen C, Cortés D, Doan L and others (2004) Recruitment studies: manual on precision and accuracy of tools. ICES Tech Mar Environ Sci 33:1-35

Berdalet E, Roldán C, Olivar MP (2005) Quantifying RNA and DNA in planktonic organisms with SYBR Green II and nucleases. Part B. Quantification in natural samples. Sci Mar 69:17-30

Bergeron JP (2000) Effect of strong winds on the nutritional condition of anchovy (Engraulis encrasicolus L.) larvae in the Bay of Biscay, Northeast Atlantic, as inferred from an early field application of the DNA/C index. J Mar Sci $57: 249-255$

Blaxter JHS (1988) Pattern and variety in development. In: Hoar WS, Randall DJ (eds) Fish physiology, Book 11. Academic Press, New York

Blaxter JHS, Hempel G (1963) The influence of egg size on herring larvae (Clupea harengus L.). J Cons Perm Int Explor Mer 28:211-240

$>$ Bligh EG, Dyer WJ (1959) A rapid method for total lipid extraction and purification. Can J Biochem Physiol 37: 911-917

Buckley LJ (1984) RNA-DNA ratio: an index of larval fish growth in the sea. Mar Biol 80:291-298

Buckley LJ, Lough RG (1987) Recent growth, biochemical composition, and prey field of larval haddock (Melanogrammus aeglefinus) and Atlantic cod (Gadus morhua) on Georges Bank. Can J Fish Aquat Sci 44:14-25

Caldarone EM, Clemmesen C, Berdalet E, Miller TJ and others (2006) Intercalibration of four spectrofluorometric protocols for measuring RNA/DNA ratios in larval and juvenile fish. Limnol Oceanogr Methods 4:153-163

Catalán IA, Olivar MP, Palomera I, Berdalet E (2006) Link between environmental anomalies, growth and condition of pilchard Sardina pilchardus larvae in the northwestern Mediterranean. Mar Ecol Prog Ser 307:219-231

Cetta CM, Capuzzo JM (1982) Physiological and biochemical aspects of embryonic and larval development of the winter flounder Pseudopleuronectes americanus. Mar Biol 71: 327-337

Chícharo MA (1997) Starvation in field caught Sardina pilchardus larvae off southern Portugal. Sci Mar 61: 507-516

Chícharo MA, Chícharo L, Valdés L, López-Jamar E, Ré P (1998a) Estimation of starvation and diel variation of the RNA/DNA ratios in field-caught Sardina pilchardus larvae off the north of Spain. Mar Ecol Prog Ser 164:273-283 
Chícharo MA, Chícharo L, Valdés L, López-Jamar E, Ré P (1998b) Does the nutritional condition limit survival potential of sardine Sardina pilchardus (Walbaum, 1792) larvae off the north coast of Spain? RNA/DNA ratios and their variability. Fish Res 39:43-54

Clemmesen C (1994) The effect of food availability, age or size on the RNA/DNA ratio of individually measured herring larvae: laboratory calibration. Mar Biol 118:377-382

Díaz E, Valencia V, Villate F (2007) Size-fractionated seston abundance and biochemical composition, over the anchovy spawning period in the Basque shelf (Bay of Biscay), during years 2000 and 2001. J Exp Mar Biol Ecol 341:45-59

> Dubois M, Gilles KA, Hamilton JK, Rebers PA, Smith F (1956) Colorimetric method for determination of sugars and related substances. Anal Chem 28:350-356

Dulčić J (1997) Growth of anchovy, Engraulis encrasicolus (L.), larvae in the Northern Adriatic Sea. Fish Res 31:189-195

Ehrlich KF (1974a) Chemical changes during growth and starvation of larval Pleuronectes platessa. Mar Biol 24: $39-48$

Ehrlich KF (1974b) Chemical changes during growth and starvation of herring larvae. In: Blaxter JHS (ed) The early life history of fish. Springer, Heidelberg, p 301-323

Ehrlich KF (1975) A preliminary study of the chemical composition of sea caught larval herring and plaice. Comp Biochem Physiol 51:25-28

Estensoro I (2006) Comparative analysis of five fish larvae species morphology in relationship with their feeding strategies. MS dissertation, Gent University, Gent

Ferron A, Legget WC (1994) An appraisal of condition measures for marine fish larvae. Adv Mar Biol 30:217-303

Folkvord A, Hunter JR (1986) Size-specific vulnerability of northern anchovy (Engraulis mordax) larvae to predation by fishes. Fish Bull 84:859-869

García A, Cortés D, Ramírez T (1998) Daily larval growth and RNA and DNA content of the NW Mediterranean anchovy Engraulis encrasicolus and their relationship to the environment. Mar Ecol Prog Ser 166:237-245

García A, Cortés D, Ramírez R, Giráldez A, Carpena A (2003) Contribution of larval growth rate variability to the recruitment of the Bay of Málaga anchovy (SW Mediterranean) during the 2000-2001 spawning seasons. Sci Mar $67: 477-490$

García A, Cortés D, Ramírez R (2005) Records of environmental variation observed on otolith microstructure and nutritional condition of Mediterranean larval sardine and anchovy. Thalassas 21:39-53

García A, Cortés D, Ramírez R, Guisande C and others (2006) Field comparison of sardine post-flexion larval growth and biochemical composition from three sites in the W Mediterranean (Ebro river coast, bays of Almería and Málaga). Sci Mar 70:79-91

Guisande C, Riveiro I, Sola A, Valdés L (1998) Effect of biotic and abiotic factors on the biochemical composition of wild eggs and larvae of several fish species. Mar Ecol Prog Ser 163:53-61

Heming TA, Buddington RK (1988) Yolk absorption in embryonic and larval fishes. In: Hoar WS, Randall DJ (eds) Fish physiology, Book 11. Academic, San Diego, CA, p 408-438

Høie H, Folkvord A, Johannessen A (1997) The influence of different parental combinations and incubation temperature on the RNA and DNA content of herring larvae at hatching: a pilot study. J Fish Biol 55:110-118
ICES (2007) Report of the ICES Working Group on the Assessment of Mackerel, Horse Mackerel, Sardine, and Anchovy (WGMHSA). ICES CM 2007/ACFM:31

Lowry OH, Rosebrough NJ, Farr AL, Randall RJ (1951) Protein measurement with the Folin-phenol reagent. J Biol Chem 87:206-210

Markwell MK, Haas SM, Bieber LL, Tolbert NE (1978) A modification of the Lowry procedure to simplify protein determination in membrane and lipoprotein samples. Anal Chem 87:206-210

Motos L, Uriarte A, Valencia V (1996) The spawning environment of the Bay of Biscay anchovy (Engraulis encrasicolus L.). Sci Mar 60:117-140

Nursall JR (1989) Buoyancy is provided by lipids of larval redlip blennies, Opioblennius atlanti-cus (Teleostei: Blenniidae). Copeia 1989:614-662

Osse JWM, Van den Boogart JGM, Van Snik GMJ, Van der Sluys L (1997) Priorities during early growth of fish larvae. Aquaculture 155:249-258

> Palomera I (1991) Vertical distribution of eggs and larvae of Engraulis encrasicolus in stratified waters of the western Mediterranean. Mar Biol 111:37-44

> Palomera I, Morales-Nin B, Lleonart J (1988) Larval growth of anchovy, Engraulis encrasicolus, in the western Mediterranean Sea. Mar Biol 99:283-291

Pepin P, Evans GT, Shears TH (1999) Patterns of RNA/DNA ratios in larval fish and their relationship to survival in the field. ICES J Mar Sci 56:697-706

> Pfeiler E (1986) Towards an explanation of the developmental strategy in lectocephalous larvae of marine teleost fishes. Environ Biol Fishes 15:3-13

Post JR, Parkinson EA (2001) Energy allocation strategy in young fish: allometry and survival. Ecology 82:1040-1051

Ramírez T, Cortés D, García A (2001) Growth of North Alboran Sea sardine larvae estimated by otolith microstructure, nucleic acids and protein content. J Fish Biol 59: 403-415

> Ramírez T, Cortés D, García A, Carpena A (2004) Seasonal variations of RNA/DNA ratios and growth rates of the Alboran Sea sardine larvae (Sardina pilchardus). Fish Res 68:57-65

Ré P (1996) Anchovy spawning in the Mira estuary (southwestern Portugal). Sci Mar 60:141-153

Rilling GC, Houde ED (1999) Regional and temporal variability in growth and mortality of bay anchovy, Anchoa mitchilli, larvae in Chesapeake Bay. Fish Bull 97:555-569

> Riveiro I, Guisande C, Lloves M, Maniero I, Cabanas JM (2000) Importance of parental effects on larval survival in Sardina pilchardus. Mar Ecol Prog Ser 205:249-258

Rosa R, Nunes ML (2003) Seasonal changes in nucleic acids, amino acids and protein content in juvenile Norway lobster (Nephrops norvegicus). Mar Biol 143:565-572

Rossi S, Sabatés A, Latasa M, Reyes E (2006) Lipid biomarkers and trophic linkages between phytoplankton, zooplankton and anchovy (Engraulis encrasicolus) larvae in the NW Mediterranean. J Plankton Res 28:551-56

Watanabe Y, Kuroki T (1997) Asymptotic growth trajectories of larval sardine (Sardinops melanostictus) in the coastal waters off western Japan. Mar Biol 127:369-378

Zöllner N, Kirsch K (1962) Über die quantitative Bestimmung von Lipoiden (Mikromethode) mittels der vielen natürlichen Lipoiden (allen bekannten Plasmalipoiden) gemeinsamen Sulfophosphovanillin-Reaktion. Z Gesamte Exp Med 135:545-561

Submitted: March 18, 2007; Accepted: February 7, 2008

Proofs received from author(s): May 26, 2008 